\title{
Partnership in Teacher Education: A Theoretical and Practical Analysis
}

\author{
Erineu Foerste1, Alberto Merler ${ }^{2}$, Andrea Vargiu ${ }^{2}$ \\ ${ }^{1}$ The Graduate School in Education, the Federal University of Espírito Santo, Espírito Santo, Brazil \\ ${ }^{2}$ Humanistic and Social Science Department, the Università degli Studi di Sassari, Sassari, Italy \\ Email:erineufoerste@yahoo.com.br,erineu.foerste@ufes.br, merler@uniss.it, avargiu@uniss.it
}

How to cite this paper: Foerste, E., Merler, A., \& Vargiu, A. (2017). Partnership in Teacher Education: A Theoretical and Practical Analysis. Creative Education, 8, 1275-1291. https://doi.org/10.4236/ce.2017.88090

Received: June 4, 2017

Accepted: July 10, 2017

Published: July 13, 2017

Copyright $\odot 2017$ by authors and Scientific Research Publishing Inc. This work is licensed under the Creative Commons Attribution International License (CC BY 4.0).

http://creativecommons.org/licenses/by/4.0/

\begin{abstract}
The aim of this study is to discuss theoretical and practical issues of the partnership in teacher education. A brief background of the debate in the last years is presented, questions about the partnership concept are introduced, the experience of the Brazilian university performing the inter-institutional work is analyzed and an overview is given of how the issue has been addressed in Québec. The current study seeks to note controversies and possible achievements of teachers in their struggles for the greater social approbation of the teaching profession. The research process benefited from documentary analysis, on-site observations and interviews; the last ones carried out in Brazil. The concept of partnership shows ambiguity. On the one hand, it is a strong ally for the implementation of official educational reforms, which puts it in scene between universities and schools. On the other hand, as a collaborative practice between the researchers and the school teachers, it helps to create new theoretical and practical basis for the initial and extended formation of the teaching professionals, in which academic knowledge and experience are articulated. In the case here analyzed, in the Brazilian scenario, the partnership helps to introduce innovations through institutional arrangements with other rationality, by which teachers are valued as collaborators in the processes of teacher training. Thus, we can affirm that the partnership is a relatively recent practice in the field of education, which involves tensions between official interests; and objectives of both collaborative work and collective struggles for the appreciation of the teaching profession of researchers at universities and teachers at schools.
\end{abstract}

\section{Keywords}

Partnership, Teacher Education, University, School, Theory and Practice

\section{Introduction}

Publications regarding the international educational context have begun to high- 
light partnerships as an increasingly adopted practice in the field of education. As formal policies in the process of training teaching professionals, partnerships have gained significant momentum since the second half of the 1980s and thus represent a powerful ally for the effectiveness of public policies since that time. Partnerships align with the need to rethink the foundations that previously sustained the process of teacher training and have been understood as part of increasing teaching professionalization and recovering the basic quality of education in the second half of the twentieth century.

Partnership in education, specifically in teacher training, is a very recent subject of research in the international scenario and is in a great phase of construction between researchers at universities and teachers at schools (Foerste, 2002). Although in Brazil, the importance of partnerships in collective struggles for a better social and political appreciation of the teaching profession has been advised (Lüdke, 1994; Gatti, 1996), there have been few specific studies on this issue. As discussed in the succeeding paragraphs, the case of the Federal University of Mato Grosso, in the midst of the Amazon Forest, has aroused interest of researchers, education professionals in general and education administrators.

The article is organizing with introduction, context and concept of partnership, types of partnership in teacher training, concrete partnership lessons in Québec, a concrete experience of partnership in teacher training in Brazil and issues for discussion.

\section{Context and the Partnership Concept}

Discussions and studies on partnership as a social practice go back to the 1970s and 1980s. These studies show that partnerships have complex configurations, with meanings emerging from the diverse activities caused by social dynamics. The concept and characteristics of partnerships depended on the subject, the context and the area in which it was used. It is worth noting that, overall, aspects of partnership are related to different fields of knowledge such as historical, economic, social, cultural and political.

Compilations of these studies were published in the early 1990s. These reviews analyze aspects related to the social context, principles and practices of partnership in both initial and extended teacher education as part of United Kingdom policy (Furlong et al., 1990; Fullan et al., 1992). The Institut National de Recherche Pédagogique (INRP) in France organized a symposium that can be considered a milestone in the academic debates about education partnership practices in that country. Trend analyses were performed on recent partnership studies by different research groups. These studies sought to better understand the concepts and experiences of educational partnerships in France (INRP, 1995). In addition, studies were published on the partnerships and knowledge of elementary school teachers conducted by the Association Québécoise Universitaire en Formation des Maitres (AQUFOM) and the Centre de Recherche sur la Formation et la Profession Enseignante (CRFPE), Laval University (AQUFOM, 1998).

All of these studies indicate that partnerships are required in teacher educa- 
tion, as a public policy, given the major economic and political transformations that occurred at the turn of the millennium and their demands for the educational field. Criticisms and alternatives for epistemological changes in the professional socialization of teachers are points that are not always agreed upon in the debate. Among public administrators and teachers and in the academic domain, there is a consensus that partnerships could be used as an emerging practice of collaboration, cooperation and sharing of responsibilities and commitments. However, these different social and institutional participants do not always understand this practice in the same way.

Starting in the second half of the 1990s, partnership in teacher education has become an innovative alternative among the public administrators in Brazil. Resolutions issued by the Ministry of Education and Culture (MEC) can be cited as examples (MEC, 2002a, 2002b). In universities, bachelor courses were emphasized by the central administration of the country, which shows an effort to analyze the problem and to implement officially government-regulated reforms in the last decade.

Which concepts are embedded in this international movement, also introduced in the Brazilian educational context, through the so-called "national guidelines for training elementary school teachers?" How can a discussion clarify the understanding of some of the terms and especially the implications of partnerships in the process of the professional socialization of the teacher, based on an analysis of the countries' experiences?

The multiple interfaces among training, action and research in educational partnerships make it a difficult task to understand the complexities and ambiguities involved in this type of work (Demailly \& Zay, 1994; Barbier, 1995; AQUFOM, 1998; Tardif et al., 2001). Negotiations are established, tasks are transferred or shared and responsibilities are identified with certain groups located in specific institutions (Stoll et al., 2006). As shown by Smedley (2001), Stoll et al. (2006), Trent \& Lim (2010) and Vandyck (2013), institutional alternatives to meet the demands of local teacher training are built through partnerships (thoughtfully and locally).

\section{Types of Partnerships in Teacher Education}

Although there is a representative set of ongoing partnership experiments in teacher education in countries worldwide (which have already resulted in some theoretical treatises about this social practice), comparisons cannot yet be made. There are peculiarities that have not been sufficiently studied (Lenoir \& Raymond, 1998b; Smedley, 2001; Vandyck, 2013). This warning, however, does not invalidate the effort or attempt to systematically understand the studies as proposed by Furlong et al. (1996).

Collaborative partnerships, as assets in the recent process of professionalization, are based on the long-articulated work of university professors who are professionals of basic education, to ensure their theoretical and practical basis in teacher education curricula (Merler et al., 2012; Merler et al., 2013; Merler et al., 
2014). This integrated work almost always present itself as a Hintergrund, i.e., the search for academic alternatives that ensure the inseparability of theory and practice.

Partnership is considered a breakthrough in teacher professionalization because it favors the articulation of the knowledge of the university and schools. However, studies emphasize that this framework coexists with two other work perspectives also called partnership. The more traditional partnership is the $d i$ rected partnership, which has long existed but has only been given this name more recently. In criticizing academia, the government uses this term to weaken the role of academia in providing training for teachers (Furlong et al., 1990; Fullan et al., 1992). Therefore, in concurrence with the official terminology, the concept of directed partnership shall also be incorporated into scientific education.

Academic debates refer to partnership as a strategy that is used by schools in the "resource" state during the process of elementary teacher education. In this type of relationship, the educational institution, i.e., the university, has all of the decision-making power in terms of what to do and how to do it. The school is considered to be a means for learning that sets the practical aspects required in the elementary education curricula. The elementary school teachers are considered to be a type of consultant who perform tasks in a given project designed and conducted by academia without a clearly defined benefit of extended education.

The partnership between the university and elementary schools in the traditional models is based on internships or the practical training of future teachers. A technical concept of training predominates in this paradigm, in which the academic knowledge dominates over the knowledge gained from teaching experience. The major emphasis of the process focuses essentially on bureaucratic control to meet the previously established steps and complete a certain number of hours in practical activities.

Even so, over time, this type of partnership has been positively evaluated, thereby validating the initial training at the university. This partnership has resulted in a significant amount of contact with the schools, enabling the development of academic projects (Furlong et al., 1990, 1996; Fullan et al., 1992). The criticisms commonly addressed to direct partnerships are based on the argument that this type of relationship between academia and elementary schools has at its base a motivation that is essentially pragmatic and reproductive, i.e., the thinking occurs at the university and the tasks are performed at the school.

The criticisms are directed at a hierarchical way of organizing the teacher education curriculum, where theoretical knowledge is considered to be more prestigious than practical knowledge and experience (Tardif et al., 1991; Tardif, 2000, 2002). The school teachers lose interest, even though the success of this partnership is attributed to an outstanding role of the elementary schools, and the lack of interest is commonly interpreted as a demonstration of lack of commitment and responsibility. Therefore, school teachers and even government sectors of the university started to recognize that the direct partnership has failed 
to meet the new requirements placed on today's teachers. The university recognizes that changes are necessary, which is a continuous challenge in the construction of a new teacher training policy, where different forms of the relationship between the institutions involved in the process are introduced and the produced knowledge is valued internally.

The government has presented its alternative, the so-called separatist partnership (from the English term "separatist"). This practice is relatively recent in elementary teacher education and is a direct result of the administration seeking more suitable alternatives to implement the purposes of public reforms. According to the government, this official alternative partnership ensures a necessary integration among the universities, schools and government, from assumptions that have not yet been made public. Thus, the authors refer to this as the "official" partnership because its institutionalization occurs by decree, essentially to meet the interests of the state administration.

The consequences of this policy for the career of teachers cannot be measured. The official discourse emphasizes the criticisms of the university's role and shows the discontentment regarding the teacher education programs developed by the universities, which do not meet the needs of the teaching profession that are required in a context of social and economic change. The higher educational institutions, according to the government, would be concerned solely with academically validating the training of elementary education teachers at the expense of greater contact with school practice and the development of studies on the processes involved in teaching activities.

Researchers and school teachers, in turn, claim that the integration of academics with schools is necessary and needs to be built from another type of partnership. Thus, the collaboration has gained momentum and resulted in negotiations that identify common objectives and respect the specific interests of each institution, combining the efforts of the initial and extended education of teachers.

\section{Concrete Lessons about Partnership: A Case from Québec}

The experience of Québec shows the construction of an inter-institutional agency by AQUFOM, founded in 1990. This entity comprises several universities and functions as an autonomous institutional agency that brings together different groups of professionals in education who are involved in teacher training activities in universities and in elementary schools. In general, this inter-institutional agency aims to intervene in official policies in the educational field and establish itself as an alternate channel to articulate the interests of educational professionals regarding the professionalization of the teaching movement.

According to Lessard and Lévesque (2001), the university in Quebec had full autonomy in teacher education in relation to the government starting from the educational reforms of the 1960s until the 1980s. The influence of the university in the initial training was driven by the need for a rupture with the past (with the training model developed by the typical school). The strengthening of science 
education was aligned with the ideals of democratization and modernization of school education at that time.

The latest reforms have failed to completely remove the university teacher education programs, thanks to the organization of teachers. The public policies in teacher education began to be guided by the most recent goal of "professionalizing education and reducing the distances between universities and the school world" (ibid, p. 95) as a part of the struggles of educational professionals for greater social recognition. A structure for framing educational professionals began to be developed, leading to discussions on teacher education, recruitment and career from a perspective that seeks to reshape the processes of the initial and extended certification of educational professionals from a perspective of collaborative partnerships.

Thus, there is a new push in teacher education, and during the 1990s, it became a domain that is defined by partnerships and requires that institutions and educational professionals to be open to negotiations. "Universities and the university students cannot conceive and perform training as if it were their property and they were the ones to determine its purposes" (Lessard and Lévesque, 2001: p. 129). The integrated work changes the programs and relationships between different social arenas and the institutions that participate in them. It may be noted that some results are now being published regarding the concrete opportunities that partnerships offer for university and schools to understand each other and to develop activities to better evaluate the current educational reality and in particular the teaching profession.

The organization of AQUFOM enables investigators, teacher representatives of at least two hundred elementary schools (school commissions), class organizations of teachers, etc., in Québec to strengthen positions that sought to influence initial and extended teacher education. Educational professionals view the operation of AQUFOM as a condition for the success of the reforms. The universities published a public recognition expressing that the repercussions of the changes were "a second birth of the colleges and education departments because it commands a greater realignment of priorities around a professional hub" (ibid, p. 128). The government approved funding to carry out a pilot project, which was developed to be a field test of the reform. Representatives of the committees are currently positively evaluating the project, recommending its enlargement with the release of new public funding to expand and sustain the program.

From this inter-institutional work emerges the figure of the associate professor, who is recruited by university teams and formed by them. The professional of elementary education works in partnership with the university in the initial training of professional educators (AQUFOM, 1998) and participates in research, in this way, stimulating the professional socialization process from a collaborative approach. Soon, the movement realized that its mission was on two fronts, the professional and the scientific. The challenge is to continue to enhance the quality of teacher education from the perspective of the knowledge involved the teaching profession. 
The discussions of Tardif et al. (2001), however, caution that it is necessary to wait a little longer to celebrate. This trend in teacher education in Quebec presents the risk of being imprisoned by the powerful forces who seek to rearticulate the power capital from a perspective of neoliberalism. In their discussions, the professionalization of teaching suffers from diverse influences that range from conservative to progressive movements; the latter defend a more critical view of the school, its internal dynamic and its relationship with society. It is difficult to know whether the university will be able to respond to all of the challenges laid by the various speakers regarding this issue. What are the universities interested in and can they meet these conditions? When are the universities willing to give up? How does this interfere with their role that has been built during the last fifty years in teacher education? After all, what is the contribution to the professionalization of teaching if there are no more effective public policies to enhance the quality of the processes and educational practices in schools?

\section{Experience from Partnerships in Teacher Education in Brazil}

Foerste (2002) analyzed some research areas developed by the Federal University of Mato Grosso (Universidade Federal do Mato Grosso, UFMT ${ }^{1}$ ) in teacher education and indicated that there are practices in which partnership is becoming a reality. Institutional actions are enabled by collective organizations and the specific functions performed by educational professionals, including the Inter-Institutional Working Group, pole coordinators for distance learning in the Open and Distance Education Center, academic advisors, and, finally, authors of teaching materials for distance education. There are other institutional dynamics involved in the UFMT experience, which can be observed in the partnerships. Some examples include the collaboration of international agencies with the university, which is the case for UNESCO and Télé Université Québec (TELUQ). The expansion of the program to various areas in the country in recent years, through agreements with other universities, is also an interesting example of partnership.

To illustrate the practice of partnership in this case, from the particular perspective of the national context, we will address two aspects that are very relevant to the UFMT experience.

\subsection{Inter-Institutional Working Group}

The Inter-Institutional Working Group (in Portuguese, Grupo de Trabalho Interinstitucional (GTI)) was created in 1993 with the basic goal of providing a new focus for teacher education in the design and implementation of policies for the professionalization of teacher in the state of Mato Grosso. In this context, UFMT provides the inter-institutional perspectives to design and implement programs to improve teachers and the educational field as a whole. The GTI has assumed a key role in collectively building a policy for the education of elemen-

\footnotetext{
${ }^{1}$ UFMT is located in the state of Mato Grosso in central-western Brazil.
} 
tary school teachers and has set policies for the initial and extended education courses at the university. This group is a pioneer in Brazil.

The contributions of the GTI are basically the innovative potential that has mobilized the definition of a broader policy of teaching professionalization as discussed in collective forums. In this educational movement in Mato Grosso, it can be observed that there is an academic and political intention defined by the university and the other partner institutions to rescue the quality of public education with education policies and the social approbation of teachers, advocated historically in the collective struggles of the field of education. At the core of this process, an academic debate has emerged precisely because the GTI minimizes the interfaces between academic thinking, the management of public education and the movement of educational professionals through its organization as a part of the teaching profession.

Thus, the role of the GTI is the result of approximately three decades of effort at the university, which can be identified without difficulty in the path and institutional history of UFMT. A key example in the history of higher education in Mato Grosso is the split mode ${ }^{2}$ of undergraduate courses for education professionals who did not or do not yet have access to a college degree through traditional paths. The university has shown its support for teachers during movements where teachers fought for better working conditions. At the same time, since its foundation in 1970, the university has assumed the challenge of thinking about questions related to pedagogical practice using projects involving teaching, research and extension activities.

The GTI takes on the role of finding alternatives to the weaknesses in the state of Mato Grosso regarding the low level of education of elementary school teachers. In this sense, GTI may be an organization similar to AQUFOM in Québec when the peculiarities of each organization are not taken into consideration. GTI's primary objectives include providing a forum to integrate the work between the university and the departments of education in the training of teachers in the early elementary school grades; helping to build an inter-institutional policy for training elementary school teachers; ensuring that the struggles for teaching professionalization in the local context are in line with the national movement for the training of education professionals, including among others, the National Association for the Training of Professional Education (in Portuguese, Associação Nacional pela Formação dos Profissionais da Educação (ANFOPE)) and the National Association of Graduate Schools and Research in Education (in Portuguese, Associação Nacional de Pós-Graduação e Pesquisa em Educação (ANPEd)); and ensuring that this does not represent a distortion of or contempt for the local particularities. Accordingly, the GTI has been participating in discussions that are increasingly providing, as a starting point, critical reflections about the practices of UFMT in dealing with issues related to teacher education. The analysis comes from the contributions of various divisions of the ${ }^{2} \mathrm{~A}$ degree in education characterized as itinerant holiday course, held in partnership with the Department of Education, encouraging access for unqualified teachers inside the university for their initial training in various subject areas (letters, history, biology, mathematics, etc.). 
organizational structure of the university, the education departments and the education workers union.

Although the GTI is seen as a dense and peculiar organization that articulates how the institutional work developed by the Institute of Education of UFMT (formerly the education department) is situated, it turns out that the GTI has favored a type of contract collaborative work between the sectors and institutions of civil society that seek to improve the quality of elementary education by investing in teacher training. The term "contract" is understood in these cases, as shown in studies by Leselbaum et al. (1995), as an intentional effort in which commitments are established to conduct joint projects between two or more social organizations. There are situations where the interests converge on the study of a certain context to understand it; in other situations, where knowledge or a realistic view already exists, the planning and execution of activities may begin. Often, these multiple dimensions appear in conjunction with each other. One can also speak of a "network" as in the study by Méreni (1995), in the sense that partnerships are characterized as inter-relationships and interactions to leverage a particular collective project.

In this sense, the study of educational partnerships shows that the idea of "project" is closely related to a sense of regional development when it is not local. Basically, two aspects appear interconnected with each other in these cases: the collaboration between various social subjects sharing common risks and benefits. The partnership, in its broad conceptualization, is the collective construction in publicly recognized spaces of an answer to a local problem in which the interests of an organization are nearly always heterogeneous, with the possibility of a negotiating sharing. The action begins by focusing on trading, and activities result from the ability of the speakers to define goals that enable a collective effort to realize practical interventions.

According Crinon (1995), the possibility that individuals in a given social group will collectively mobilize to solve a certain problem indicates that it is possible to learn how to "work with others, build projects, and identify the particularities and functions of each one in the common work to set the goals, means and limits of this or that type of collaboration to reflect on the possibilities and potentials of the partnership" (p. 135).

When considering the role played by the GTI, one can say that the experiences from the partnerships in the state of Mato Grosso in the training of educational professionals are considered to be inter-institutional initiatives within that particular state. These partnerships have changed over time and have consolidated into an inter-institutional policy of teaching professionalization, where teacher education and its social approbation are considered to be inseparable dimensions in the collective reform of elementary schools and committed to build a more socially relevant project.

\subsection{Academic Advisor}

The academic advisor is a new feature introduced in the teacher education 
process in the Elementary Education course "Elementary School Sequence" at UFMT, in the form of an open and distance education course offered for teachers already working in schools. The academic advisor seeks to meet the demands for systematic academic service at the institution in the partnership, which had been diagnosed over the years via the graduate courses evaluations.

The traditional role of tutoring in Distance Education was analyzed and adapted for the regional context, taking into account the benefits offered by the face-to-face interactions (Freire, 1979, 1996; Bakhtin, 1986). The interaction of the various social parties within the teams engaged in the process, beginning with the GTI, had to be valued, primarily those benefiting the student teacher, through varied learning situations such as planning meetings, individual and/or group mentoring, review meetings for the help centers and hubs, thematic seminars, the collective understanding of videos to participate in teleconferences, etc.

Collaboration became a tool to articulate among the different parties involved in the process, gradually encouraging further synthesis of the knowledge from academia and the knowledge from the elementary school. This dynamic contributes to a substantial flexibility and opens real opportunities for innovation. In the partnership, a wide range of activities is shared, including the production of educational materials, the creation and use of technologies, the development of different assessment tools, and finally, the collective debates that led to the development of academic research projects.

Engaging in educational research fulfills an important aspect of the work of the academic advisor as a collaborator of the academy. The studies of Lüdke et al. (2001) indicated that teacher research is considered to be a central theme for the professional socialization process of teachers. The university staff and the elementary school teacher combine their efforts and mobilize themselves to seek alternatives to academic theories to overcome a conception that is quite rooted in the educational environment, that knowledge is something given or already done. Thus, it is observed that the academic advisor' $s$ role at UFMT resembles that of the associate professor ${ }^{3}$ at Québec. Both represent the so-called "new subjects" introduced in the academy as contributors in the process of training of educational professionals through institutional projects.

The academic advisor ensures the participation of those graduate students of elementary education enrolled in an Education course who have experience in teaching. More than that, the academic advisor is recruited by institutional arrangements secured for the partnership, which is required to offer a specialized course in distance education at UFMT. The advisor's final work consists of designing and developing a research project for a training course for early elementary teachers in a Distance Education mode and the advisor operates as a contributor to the university. Without the partnership of the universities with the education departments, such curriculum would be hampered. This dynamic is decisive in the construction of the educational identify of the professional, gene-

${ }^{3}$ An associate professor is recruited by the University in partnership with the State to collaborate with teams of university faculty for teacher education and to conduct research on the teaching process and the professional socialization of teachers. 
rating channels and workspaces that are more integrated between the university and elementary school teachers.

The teacher's work, in its traditional form, has been exposed to significant changes if we considered academic mentoring as a typical practice of collaboration. Inherent in the academic advisor's role is inserting a dynamic quality that is enhanced by the introduction of new areas of training and new knowledge. The practice of collaboration with the academic advisor provides spaces to overcome dichotomies that have been reinforced by technical reasoning, through which a hierarchy of knowledge has been legitimized where initial and extended education are split by the hypertrophy of the theoretical aspects in the curricula of teacher education at the universities (Candau, 1988; Lüdke, 1994; Gatti, 1996; INEP/ANPEd, 2002).

The university benefits from this flexibility. Studies show that academia is gradually incorporating new knowledge in teacher education through new subjects and new spaces. The knowledge of experience is built by educational professionals who work within schools. In this collaborative relationship, an appreciation of the small spaces previously regarded for the extended education of school and university teams is emerging.

\section{Questions for Debate}

In recent years, another reality is emerging in teacher education, with concrete possibilities for building a new culture of professional teaching. Collaborative partnership is regarded as an essential dimension in this movement. Educational professionals are making efforts to introduce different types of theoretical and practical knowledge and/or non-hierarchical knowledge in the initial and extended training curriculum, such as academic knowledge and the expertise of practicing teachers. It is understandable that the professional identity of the teacher is at the interface between these types of knowledge, which is built and/or acquired in a complex and multifaceted process of formation and work experience. These professionals should have access to different areas of educational knowledge, based on the interaction of the individuals and institutional spaces. What criteria should be used to recognize individuals, places and specific knowledge that, when linked to one other, can be decisive for the theoretical and practical training of the teacher and thereby qualify the teacher to act independently regarding the problems experienced by the profession, both inside and outside of school?

Partnership practices in teacher education in England, France, Portugal, Canada etc. and in Brazil, reviewed here, aid in understanding the experiences of training of teaching professionals at the university of our era. Devices to institutionalize the collaboration practices between researchers that act in teacher training courses and elementary school teachers are introduced. Our research enable us to affirm that there are important indications that the field of teaching and its professionals are receiving more power and credibility in the formation of a new generation of professors, a trend supported by the official policies of 
several countries.

Since the 1980s, however, and with greater intensity from the 1990s, economic, social and cultural policies have grown on the international scenario based on neoliberal assumptions, for deregulation of the Welfare State, against social rights won by the social populations less privileged in class society. Through their social and political organizations, teachers and researchers, especially those of the Faculties of Education, expressed resistance to this model of government management. It is fundamentally questioned the loss of autonomy of these important individuals in the process of professional socialization of teachers. Education is demanded as a right of people and duty of the State, and it is incumbent upon it to promote public policies and guarantee funding for collaborative partnerships in conducting research and development of both initial and extended training courses in teaching.

In recent official reforms, there is the risk of considering the teacher as a simple conduit or transmitter of knowledge as stated by Nóvoa (1992a, 1992b) and Lüdke (1998a, 1998b). From this perspective, the educational changes decreed by government agencies may end up strengthening technical or instrumental reasoning, the epistemology of which does not include the basic understanding that teaching triggers elaborative processes of theoretical and practical knowledge of the educational professionals, strengthened by the theoretical and practical assumptions of the collaborative partnership between the university and the school.

The figure of the academic advisor in Brazil, for example, in the pioneer case of UFMT, emerges from inter-institutional dialogues in the GTI created in the State of Mato Grosso. Problems of teacher education are analyzed in a negotiation movement between representatives of universities and schools, as protagonists of schooling, with government participation. The academic advisor, who in Quebec is known as an associate professor, introduces in the initial formation an innovation that is widely accepted and applauded by schools, because it acknowledges as university collaborators, teachers who work and know inside the educational organizations. With this new trainer, unconventional collaboration relations until then are established. Recognizing the knowledge of experience, characterized with a low prestige in the traditional curricula of the education courses in the academic world, as a formative dimension of new generations of teachers. This raises the questioning of the technical rationality that is very present in graduate courses, which the relationship between theory and practice in the qualification of teaching is dichotomized. The collaborative partnership, in this sense, favors the collective construction of contributions in order to overcome problems arising from the pernicious hypertrophy of organized knowledge in disciplines, due to its appreciation in the academic world.

The teaching practice at schools is directly related to the knowledge that have specific constituencies of the professional identity of the teacher, without hierarchization between academic knowledge as a place of formation and experience in the teaching process as the space of savoir-faire This knowledge builds 
the professional identity of the teacher (AQUFOM, 1998; Tardif, 2000, 2002). To Nóvoa, a greater appreciation of the teacher assumes the collective construction of a policy that actually helps "beyond this dichotomy (the split between field work and the initial formation of professionals via education curricula), which does not have any relevance today, by adopting professional models that are based on solutions resulting from a partnership between higher education institutions and schools" (Nóvoa, 1992b: p. 26).

For this, the teacher represents the governmental interests, which are becoming stronger in almost every capitalist country. In this context of analysis, it is necessary to locate the public reforms. These reforms are a part of the New Right agenda and combine neoliberal commitments and market forces in a Thatcherite project of the state and free society (Whitty, 1993, 1998; Torres, 1998; Lüdke \& Moreira, 1998), which are emphasized nowadays especially in England and United States.

In this political movement of neoliberal deregulation, the State began implementing changes not only in teacher education, using partnership as a theme, but in the entire process of human development. Researchers have discussed the question of how long this international movement has been characterized as essentially opposed to the teacher professionalization project developed by the university by looking at the long history of dialogue with the teachers, which is based on how the teaching profession is defined from reflective professional discussions. There are enough obscured interests of the government, in the words of Whitty $(1993,1998)$ and Goodson (as cited in Lenoir, 1998), to degrade and even dismantle the academic programs that are focused on building the autonomy and identity of teachers as professionals.

Caution and further studies appear to be required regarding the promises of partnerships, at least the one defended by the government. How will partnerships benefit teachers? What consequences will result from their official adoption to strengthen or even undermine the fight of teachers for the further appreciation of their social role? Which tensions are enhanced by this new modality between the subjects and institutions involved? Which disruptions or blocks are being generated, and how is this reflected in the current teaching professionalization process?

The partnerships should be carefully adopted to avoid confusion and disruption in making decisions about what do and how to do it. Ambiguities regarding the understanding of the existing partnership practice constitute in difficulties and obstacles to collaborative work, involving government, university and school sectors. For researchers and teachers it is basically a consideration of official power in financial terms. Question: how long should the partnership be and what additional financial resources are needed to follow through with the new responsibilities and commitments by each subject or group involved on it? This is a dimension that is opened, especially from the perspective of the government. Without clear official response, tensions and obstacles that hinder the collaborative work among university and schools teams are remained. 
For Smedley (2001), there are other controversial issues to be considered, which include 1) the widespread lack of mobility or flexibility in institutions, 2) a delay in releasing public funds, 3 ) the continuity of projects as public policy, 4) little social recognition of the teacher, 5) the workload for the elementary school teacher and 6) the small number of university professors and school teachers who are genuinely interested in and qualified for taking part in a project of this political and academic scale.

The diversity of the terms and their meanings as related to partnerships, such as negotiation, participation, collaboration, cooperation, shared management, etc., must be further assessed by investigative processes. Arguments between the government and teachers in the context of partnerships indicate that there is a certain amount of consensus that the more that the conceptual designs and terminology are made clear between teaching professionals and academia, the more that the ability to reason and negotiate with the educational administrative bodies is enhanced. Today, there is an awareness of the growing need for reform, particularly in the field of education.

Despite the array of conceptions and practices of partnership in teacher education, Lenoir \& Raymond (1998a) suggest that there are two aspects that appear to merge as an important area of research. On one side are the collaborative contracts between the university and schools so that trainees can experience pedagogical practice, developments in the interactive processes and communication between the individuals involved; on the other side are the research projects developed jointly by academia and institutions of elementary education. Although this is still in the early stages in the context assessed by the authors (i.e., Québec), there are expectations that the individuals involved in this process will benefit in terms of pedagogical innovation in schoolwork and at universities. Regarding the inter-institutional dimension present in the GTI, in the Brazilian case analyzed here, it is necessary to evaluate better the issues arising from local cultural realities, especially regarding the participation in the negotiation boards of populations that produce their material and symbolic existences through modes of unconventional production, as is the case of riparians, extractivists, quilombolas ${ }^{4}$ and indigenous people. What education do these individuals demand from the state, schools and universities?

The surveys must be deepened to build academic standards that help to create a concept of partnership in teacher education also in contexts of cultural diversity, as a part of the more complex process of the professional socialization of teachers, the challenges that are posed for the schools and the teachers who work there. This means that partnerships should be understood as key allies to boost teaching professionalization, especially in the movement for the collective building of the teaching ethos that refers to a new professionalism of teachers. In this collaborative effort, the government has an important contribution to present, for the collective discussion and implementation of public policies of the teaching profession, with appreciation of the teaching work. New possibili${ }^{4}$ They are communities organized by fugitive African and Afro-Brazilians during the slavery period in Brazil. 
ties can emerge and consolidate from collaborative practices in the initial and extended formation, that are defined and redesigned by education professionals (researchers and school teachers) while the subjects are engaged in the construction of their identity and professional autonomy. The analysis in this study of the available publications and practical experiences of partnership, included a consideration of the conceptual issues, the figure of the associate professor introduced by AQUFOM in Québec, the establishment of the GTI and the cooperation with academic advisors in the concrete experience of UFMT in Brazil.

Partnership in teacher training can contribute to stimulate reflection and collective debate, at a time when cultural diversity is demanding another way of producing school education. Collaborative partnership in education is characterized as permanent dialogical academic processes between researchers and school teachers, funded by public policies. Thus, interinstitutional efforts between universities, schools and government are added to strengthen the profession of teacher with a growing overcoming of dichotomies between theory and practice in the training and work of teaching professionals.

\section{References}

AQUFOM (1998). Enseignants de métier et formation initiale; des changements dans les rapports de formation à lénseignement. Paris/Bruxelles/Sherbrooke: AQUFOM/De Boek Université.

Bakhtin, M. (1986). Marxismo e filosofia da linguagem (Marxism and the Philosophy of Language). Sao Paulo: Hucitec.

Barbier, J.-M. (1995). Tendences d'evolution de la formation et place du partenariat. In INRP, Etablissements et partenariats: Stratégies pour des projets communs (Actes du colloque) (pp. 43-54). Paris: INRP.

Candau, V. M. et al. (1988). Novos rumos da licenciatura (New Directions of Teacher Training). Rio de Janeiro: Puc-Rio/INEP.

Crinon, J. (1995). Le partenariat: Pour former ou pour gérer? In INRP, Établissements e partenariats: Stratégies pour des projets communs (pp. 132-138). Paris: INRP.

Demailly, L., \& Zay, D. (1994). Gestion de la recherche et formation de formteurs d'enseignants. Recherche et Formation, n. 17.

Foerste, E. (2002). Parceria na formação de professores: Do conceito à prática (Partnership in Teacher Education: From Concept to Practice). Rio de Janeiro: PUC-Rio (PhD Thesis).

Freire, P. (1979). Pedagogia do oprimido (Pedagogy of the Oppressed). São Paulo: paz e Terra.

Freire, P. (1996). Pedagogia da autonomia (Pedagogy of Autonomy). Sao Paulo: Paz e Terra.

Fullan, M. et al. (1992). Teacher Development and Education Change. London/Washington: Falmer Press.

Furlong, J. C. et al. (1990). Partnership in Initial Teacher Training. London: Cassel.

Furlong, J. C. et al. (1996). Re-Defining Partnership: Revolution or Reform in Initial Teacher Education? Journal of Education for Teaching, 22, 39-55.

Gatti, B. A. (1996). Analysis toward a Policy Framework for Teacher Training for Primary Schools. Brazil: CONSED. 
INEP/ANPEd (2002). Teacher Training in Brazil (1990-1998). Brazil: MEC/INEP/ Comped.

INRP (1995). Etablessements partenariats: Stratégies pour des projets comuns. Paris: INRP.

Lenoir, Y., \& Raymond, D. (1998a). Une approche nouvelle, des points de vue diversifiés. In AQUFOM (Ed.), Ensignants de métier et formation intiale; des changements dans les rapports de formation à l'ensignement (pp. 35-46). Paris/Bruxelles/Sherb-rooke: AQUFOM/De Boeck Université.

Lenoir, Y., \& Raymond, D. (1998b). Enseignants de métier et formation initiale: Une problématique divergente et complexe. In AQUFOM (Ed.), Ensignants de métier et formation intiale; des changements dans les rapports de formation à l'ensignement (pp. 46-102). Paris/Bruxelles/Sherbrooke: AQUFOM/De Boeck Université.

Leselbaum, N. et al. (1995). Le définition du partenariat. In INRP (Ed.), Établissements e partenariats: Stratégies pour des projets communs (pp. 342-347). Paris: INRP.

Lüdke, M. (1994). Institutional Assessment: Teacher Training for Primary and Secondary Education (The Undergraduate Programs). Brazil: CRUB.

Lüdke, M. (1998a). Formação inicial e construção da identidade de professores de $1^{\circ} \mathrm{Grau}$ (Initial and Phase and Construction of First Grade Teachers Identity). In V. M. Candau (Ed.), Magistério: Construção cotidiana (Magisterium: Daily Construction) (pp. 110-125). Petrópolis: Vozes.

Lüdke, M. (1998b). The Professional Socialization of Teachers-Step III: The Educational Institutions (Research Report). Rio de Janeiro: PUC-Rio.

Lüdke, M. et al. (1998). Impact of International Trends on the Training of Our Teachers. Educação e Sociedade, 20, 278-298.

Lüdke, M. et al. (2001). The Professors and the Researchers. Campinas: Papirus.

MEC (2002a). Resolution no 1/2002. Brasília: CNE.

MEC (2002b). Resolution no 2/2002. Brasília: CNE.

Méreni, C. (1995). Le partenariat em formacions: Nature et dispositif. In INRP (Ed.), Établessements partenariats: Stratégies pour des projets comuns (pp. 244-248). Paris: INRP.

Merler, A. et al. (2012). Educação do campo: Diálogos interculturais em terras capixabas. Vitória: EDUFES.

Merler, A. et al. (2013). Educação do campo e culturas: Uma discussão sobre pedagogias alternativas. Visioni Latinoamericane, 5, 30-41.

Merler, A. et al. (2014). Memórias e imagens da formação do professor do campo no Brasil. Visioni Latinoamericane, 11, 7-22.

Nóvoa, A. (1992a). Formação de professores e profissão docente (Training of Teachers and the Teaching Profession). In A. Nóvoa, (Ed.), Os professores e sua formação (Teachers and Their Training) (pp. 15-33). Lisboa: Dom Quixote.

Nóvoa, A. (1992b). O passado e o presente dos professors (The Past and Present of Teachers). In A. Nóvoa, (Ed.), Profissão professor (Teaching Profession) (pp. 13-30). Porto: Porto Editora.

Smedley, L. (2001). Impediments to Partnership: A Literature Review of School-University Links. Teachers and Teaching: Theory and Practice, 7, 189-209. https://doi.org/10.1080/13540600120054973

Stoll, L. et al. (2006). Professional Learning Communities: A Review of the Literature. Journal of Educational Change, 7, 221-258. https://doi.org/10.1007/s10833-006-0001-8 
Tardif, M. (2000). Saberes profissionais dos professores e conhecimentos universitários: Elementos para uma epistemologia da prática profissional dos professores e suas conseqüências em relação à formação para o magistério (Professional Knowledge of Teachers and University Knowledge: Elements for an Epistemology of Professional Practice of Teachers and Their Consequences in Relation to Training for Teaching). Revista Brasileira de Educação, 13, 5-24.

Tardif, M. (2002). Saberes docentes e formação professional (Teacher Knowledge and Training). Petrópolis: Vozes.

Tardif, M. et al. (2001). Formação dos professores e contextos sociais; perspectivas internacionais (Training of Teachers and Social Contexts; International Perspectives). Porto: Rés-editora.

Torres, R. M. (1998). Tendência da formação docente nos anos 90 (Trend of Teacher Education in the 90s). In PUC-SP (Ed.), Novas políticas educacionais; críticas e perspectivas (New Educational Policies; Criticisms and Perspectives) (pp. 173-191). Sao Paulo: PUC-SP.

Trent, J., \& Lim, J. (2010). Teacher Identity Construction in School-University Partnerships: Discourse and Practice. Teaching and Teacher Education, 26, 1609-1618.

Vandyck, I. (2013). Fostering Community Development in School-University Partnerships. Amsterdam: Datawyse BV.

Whitty, G. (1993). Education Reform and Teacher Education in England in the 90s. Journal of Education for Teaching, 19, 263-275.

Whitty, G. (1998). Control of the Curriculum and Quasi-Markets, the Recent Education Reform in England and Wales. In PUC-SP (Ed.), New Educational Policies; Criticisms and Perspectives (pp. 193-213). Sao Paulo: PUC-SP.

Submit or recommend next manuscript to SCIRP and we will provide best service for you:

Accepting pre-submission inquiries through Email, Facebook, LinkedIn, Twitter, etc. A wide selection of journals (inclusive of 9 subjects, more than 200 journals)

Providing 24-hour high-quality service

User-friendly online submission system

Fair and swift peer-review system

Efficient typesetting and proofreading procedure

Display of the result of downloads and visits, as well as the number of cited articles

Maximum dissemination of your research work

Submit your manuscript at: http://papersubmission.scirp.org/

Or contact ce@scirp.org 